\title{
REVIEW
}

\section{Bacillus anthracis}

\section{R C Spencer}

J Clin Pathol 2003;56:182-187

The events of 11 September 2001 and the subsequent anthrax outbreaks have shown that the West needs to be prepared for an increasing number of terrorist attacks, which may include the use of biological warfare. Bacillus anthracis has long been considered a potential biological warfare agent, and this review will discuss the history of its use as such. It will also cover the biology of this organism and the clinical features of the three disease forms that it can produce: cutaneous, gastrointestinal, and inhalation anthrax. In addition, treatment and vaccination strategies will be reviewed.

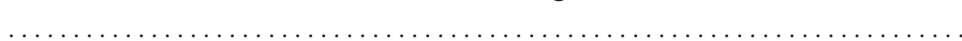

Correspondence to: Dr R C Spencer, Public Health Laboratory, Bristol Royal Infirmary, Marlborough Street, Bristol BS2 8 HW, UK;

robert.spencer@ ubht.swest.nhs.uk

Accepted for publication 24 September 2002
O n 11 September 2001, American Airlines, Flight 11 hit the North Tower of New York's World Trade Center, at 08.48 Eastern Standard Time, followed by United Flight 175 at 09.18 hitting the South Tower. The South Tower collapsed, followed by the North Tower at 10.28. In 100 minutes the world had changed for ever. Simultaneously, American Airlines Flight 77 hit the West Wing of the Pentagon Building in Washington DC. The United States of America, the most powerful country on Earth, had succumbed to the ultimate asymmetric threat. In times past, military leaders from Alexander the Great to Field Marshall Montgomery had fought battles in terms of symmetric warfare: the enemy was known and could be identified, goals were clearly stated, weaponry was understood, and rules of engagement agreed. Asymmetric warfare is exactly the reverse: unknown, invisible, often with undefinable aims, mainly through attacks on civilian targets and with a complete disregard for collateral damage, including the perpetrators' lives. There is no pattern, balance, consistency, or coherence associated with this type of warfare. The response will not just be military but also political, diplomatic, psychological, and financial and must be sustained. Because of this multiagency involvement in formulating an effective response, progress will undoubtedly be difficult. Subsequent to this outrage, on 5 October 2001 a 63 year old white man in Florida died of inhalation anthrax, the first person to develop this disease in the USA for 25 years. ${ }^{1}$ Bioterrorism, in the form of letters containing the Ames strain of Bacillus anthracis spores, had also arrived. After the sending of probably six such letters, as of 26 January 2002, a total of 11 cases of inhalation anthrax (five of these patients died) and 11 (seven confirmed and four suspected) cases of cutaneous anthrax have been identified. Long considered a potential biological warfare agent, ${ }^{2-4}$ Bacillus anthracis had been investigated and weaponised for potential use against animals in World
War I (Germany) ${ }^{5}$ and both animals and man in World War II.

$$
\begin{aligned}
& \text { "Bioterrorism, in the form of letters } \\
& \text { containing the Ames strain of Bacillus } \\
& \text { anthracis spores, had also arrived" }
\end{aligned}
$$

Dr Paul Fildes headed the British effort at Porton Down in the 1940s and by November 1940 had determined that the most effective way to use a biological warfare agent would be to disseminate an aerosol of lung retention size particles from a liquid suspension of bacteria in a bursting munition, such as a bomb, so that effective concentrations would be inhaled by anyone in the target area. $^{78}$

The British biological warfare offensive effort concentrated on anthrax and between 1942 and 1943 anthrax bombs were tested on the island of Gruinard, off the North West coast of Scotland. The so called $\mathrm{N}$ bomb contained 106 special bomblets charged with anthrax spores. Another effort was the production of over 5 million anthrax infected cattle cakes, which would have been dropped over Germany in an attempt to decrease meat stocks by some $30 \%$. Events overtook plans to put these into operation.

In 1979, a sudden outbreak of pulmonary anthrax occurred in Sverdlovsk (former Soviet Union), downwind of a military complex, compound 19, because of the failure to activate air filters. Between 66 and 105 people died.

In a military operation it is anticipated that anthrax would be unlikely to cause severe disruptions to operations, although residual contamination of the ground would occur, as shown by the Gruinard experience. Anthrax is more of a danger to the civilian population of a city. Based on scientific calculations, the World Health Organisation $^{10}$ gave an estimate of possible casualties following the release of $50 \mathrm{~kg}$ of dried anthrax powder by aerosolisation for two hours on a city of 500000 inhabitants. It was calculated that 95000 deaths would occur, with 125000 individuals being incapacitated. The strain on medical resources would be tremendous, leading to bed requirements for 12500 individuals $(10 \%$ of those incapacitated), antibiotics for 60 days for 125000 people, and the disposal of 95000 dead. This would almost certainly lead to a rapid total breakdown in medical resources and civilian infrastructures.

In view of these recent events, ${ }^{11}{ }^{12}$ it is opportune to review the disease of anthrax and its causative agent $B$ anthracis. The reader is encouraged to read other similar texts. ${ }^{13-15}$

\section{BACTERIOLOGY}

Bacillus anthracis, the organism that causes anthrax, derives its name from the Greek word for 
coal, $B$ anthrakis, because of its ability to cause black, coal-like cutaneous eschars. Bacillus anthracis, a large Gram positive, aerobic, spore bearing bacillus, $1-1.5 \times 3-10 \mu \mathrm{m}$ in size, is the only obligate pathogen within the genus bacillus. ${ }^{16}$ It is convenient to class $B$ anthracis within the $B$ cereus group, which comprises $B$ cereus, $B$ anthracis, $B$ thuringiensis, and $B$ mycoides by phenotype. ${ }^{17}$ Although it is not possible to discriminate between species by $16 \mathrm{~S}$ rRNA sequencing, multiple locus variable number tandem repeat analysis and amplified fragment length polymorphism provide clear evidence that $B$ anthracis can be reliably distinguished from others of the $B$ cereus groups. ${ }^{18}{ }^{19}$ In addition, although $B$ anthracis is one of the most molecular monomorphic bacteria known, all known strains have been separated into five categories (allowing for geographical identification) on the basis of variable numbers of tandem repeats in the variable region of the VrrA gene. ${ }^{20}$ Unlike the other members of the $B$ cereus group, $B$ anthracis is non-motile and non-haemolytic on horse (or sheep's) blood agar, grows at $37^{\circ} \mathrm{C}$, and forms typical white colonies with bee's eye appearance (that is, oval, slightly granular but not dry, about $2 \mathrm{~mm}$ in diameter), which are characteristically tacky on teasing with a loop. Spores do not form in host tissues unless the infected body fluids are exposed to air. When nutrients are exhausted, resistant spores form that can survive in soil for decades. ${ }^{21}$ These spores then germinate when exposed to a nutrient rich environment, such as the tissues or blood of an animal or human host. In infected blood or tissues, the bacilli are frequently present in short chains, surrounded by the polypeptide capsule, which can be visualised under the microscope if stained with polychrome methylene blue (McFadyean stain) or highlighted with Indian ink. In stained smears from colonies cultivated on plates there is no capsule unless the medium contains $0.7 \%$ biocarbonate or $5 \%$ serum and the plates are incubated in 5-10\% carbon dioxide. ${ }^{22}$ Provided no antibiotics have been prescribed, there is usually no difficulty in isolating $B$ anthracis from clinical specimens. However in environmental sampling because of the presence of other Bacillus spp, a selective medium is recommended, such as polymixin lysozyme EDTA thallus acetate agar. ${ }^{23}$

\section{PATHOGENESIS}

The major virulence factors of $B$ anthracis are encoded on two virulence plasmids $\mathrm{pXO1}$ and $\mathrm{pXO} 2{ }^{24}{ }^{25}$ The tri-toxin bearing plasmid pXO1 is 184.5 kilobase pairs ( $\mathrm{kbp}$ ) in size and codes for three toxins, which cause haemorrhage, oedema, and necrosis. ${ }^{26}$ They comprise the $83 \mathrm{kDa}$ lethal factor, $89 \mathrm{kDa}$ oedema factor (calmodulin dependent adenylate cyclase), and the $85 \mathrm{kDa}$ protective antigen, which contains the $20 \mathrm{kDa}$ host cell receptor component. ${ }^{27-29}$ The exotoxins are binary, with the protective antigen acting as the binding domain that allows entry of the toxin into the host cell. The smaller capsule bearing plasmid pXO2 is $95.3 \mathrm{kbp}$ in size and encodes three genes (cap B, cap C, and cap A) involved in the synthesis of the polyglutamyl capsule that inhibits host phagocytosis of the vegetative form of $B$ anthracis. ${ }^{30}$ Both plasmids are necessary for full virulence; loss of either results in an attenuated strain. Sterne, such as attenuated strain, carries pXOl and therefore can synthesise exotoxin, but does not have a capsule. ${ }^{24}$ Infection occurs after introduction of the spore through a break in the skin (cutaneous anthrax) or entry through mucosa (gastrointestinal anthrax). After ingestion by macrophages at the site of entry, germination of the vegetative form then occurs, followed by extracellular multiplication, together with the production of capsule and toxins. In inhalation anthrax, spores of $1-2 \mu \mathrm{m}$ in diameter are inhaled and deposited in the alveolar spaces from where they are transported by the lymphatics to the mediastinal lymph nodes, where they cause regional haemorrhagic lymphadenitis. Vegetative bacteria then spreads through blood and lymph where, if unchecked, they cause severe septicaemia. In turn, large amounts of the exotoxins are produced, which are responsible for the overt symptoms and death. In a rhesus monkey inhalation anthrax model, germination can occur up to 60 days after exposure. ${ }^{31}$ Such observations are the basis for recommending antibiotic prophylaxis for 60 days in response to inhalation exposure. Indeed, in the 1979 Sverdlovsk outbreak, all known cases of inhalation anthrax, following accidental discharge of anthrax spores from a military production facility, occurred within six weeks of the release. ${ }^{9}$

\section{EPIDEMIOLOGY}

Anthrax is a worldwide zoonosis to which most animals, especially grazing herbivores, are susceptible. In natural conditions, human infections (predominantly cutaneous) usually result from contact with infected animals or contaminated animal products, such as hides or wool. Cases of inhalation anthrax (woolsorters' disease) have occurred in enclosed factory spaces where large scale processing of hides and wool took place. The ability of the anthrax spore to produce disease by the respiratory route is not high. ${ }^{32}$ Inhaled spores of $>5 \mu \mathrm{m}$ pose no threat because they are cleared from the lung by the mucociliary escalator system. Lincoln and colleagues quote a spore load figure for sheep, generally regarded as very susceptible to anthrax, of $200000 .^{32}$ Humans are generally regarded as being moderately resistant to anthrax. Using air sampling techniques, Dahlgren and co-workers ${ }^{33}$ estimated that in one woollen mill, workers were inhaling between 600 and 1300 spores during an eight hour shift with no ill effects.

\section{"Anthrax is a worldwide zoonosis to which most animals, especially grazing herbivores, are susceptible"}

Zimbabwe saw the largest human epidemic to date, where more than 10000 human cases, nearly all of them cutaneous, were reported between 1979 and $1985 .^{34}$ Three main lessons were learnt from this outbreak, namely: (1) the importance of vaccinating livestock on a regular basis in areas of endemicity; (2) direct contact with infected livestock has a major role in human acquisition; and (3) there seems to be little risk of cross infection from infected patients to health care workers or other patients.

\section{CLINICAL FEATURES}

Anthrax takes one of three forms. ${ }^{14}{ }^{15}$ By far the most common is cutaneous anthrax, which accounts for over $90 \%$ of all human cases and is acquired through a lesion on the skin. The other two forms are gastrointestinal anthrax and pulmonary, or inhalation, anthrax.

\section{Cutaneous anthrax}

After infection via an abrasion, cut, or possible insect bite, a small pimple or papule will develop within two to three days, although there are reports of incubation periods as short as 12 hours or as long as 19 days. ${ }^{35}$ Over the next 24 hours a ring of vesicles develops, followed by ulceration of the central papule, which dries to form the classic black eschar, which in turn enlarges to cover the drying vesicle. Pus will only be present if the lesion becomes secondarily infected with pyogenic bacteria, such as Staphylococcus aureus. The lesion, which is always painless, may be small or large and is always surrounded by oedema. Usually, by the fifth or sixth day a thick black eschar, firmly adherent to the underlying tissue, has developed. The bacilli remain localised to the lesion in uncomplicated cutaneous anthrax, although adenitis of the regional lymph nodes is not uncommon. Fever is rarely present. Ten days after the appearance of the original lesion the eschar begins to resolve slowly, over two to six weeks, irrespective of treatment, ${ }^{36}$ and resolution is usually completed with minimal scarring. In 
untreated anthrax, about $20 \%$ of patients may develop septicaemia and die, but with the use of appropriate antibiotics the mortality rate is $<1 \%$. Cutaneous anthrax should always be considered when patients who have had contact with animals or animal products present with painless ulcers associated with vesicles and oedema.

\section{Gastrointestinal anthrax}

This form of disease results from the ingestion of undercooked meat from animals with $B$ anthracis. The incubation period is two to five days. Few, if any, countries outside Africa and Asia have recorded cases of this form of anthrax. The characteristic eschar occurs most often on the wall of the terminal ileum or caecum, ${ }^{37}$ although the oropharynx, stomach, duodenum, and upper ileum can be affected. ${ }^{39}{ }^{40}$ It has two clinical forms: abdominal and oro-oesophageal anthrax. In abdominal anthrax initial symptoms are nausea, vomiting and anorexia, and fever. As the disease progresses, severe abdominal pain resembling an acute abdomen, haematemesis, and bloody diarrhoea occur, followed by septicaemia and death. ${ }^{41}$ The symptoms result from severe and widespread necrosis of the initial eschar, together with extreme oedema of intestines and mesentary, and enlargement of local mesenteric lymph nodes. In oro-oesophageal anthrax, the clinical manifestations include sore throat, dysphagia, fever, cervical lymphadenopathy, and oedema. If an early diagnosis is made then patients can be cured, but because of the non-specific presentation diagnosis is difficult, resulting in a high mortality rate.

\section{Inhalation anthrax}

Until the recent events of 11 cases of inhalation anthrax following deliberate contamination of US mail, ${ }^{42}$ inhalation anthrax had always been associated with industrial exposure to spores in textile or tanning industries. With improved industrial hygiene practice and immunisation the numbers of cases have fallen dramatically. ${ }^{43}{ }^{44}$ In 1979, after an apparent accidental release of anthrax spores from a military facility in Sverdlovsk of the former Soviet Union, the largest outbreak of inhalation anthrax in the 20th century occurred. ${ }^{95}$ The illness begins insidiously with "flu-like" symptoms of mild fever, fatigue, malaise, myalgia, and non-productive cough, usually two to five days after the initial exposure. This mild initial prodromal phase, which usually lasts about 48 hours, suddenly ends with the development of an acute illness characterised by acute dyspnoea, stridor, fever, and cyanosis. On examination at this time, the findings include fever, tachypnoea, cyanosis, tachycardia, moist rales, and evidence of pleural effusion. Terminally, the pulse becomes extremely rapid and faint, dyspnoea and cyanosis worsen, the patient becomes extremely disorientated, and this is quickly followed by coma and death. ${ }^{46-48}$ Meningitis occurs in approximately 50\% of patients. Until recently, the mortality rate was estimated to be $>95 \%$; however, of the 11 known cases to date in the USA, six of the patients survived, providing a death rate of $45 \%$. This lower figure may reflect the success of appropriate antibiotic treatment, together with full intensive care support, including draining of the pleural effusions. Jernigan et al have reported on the first 10 US cases of inhalation anthrax associated with the recent bioterrorism event. ${ }^{42}$ Epidemiological investigation indicated that the outbreak from 4 October to 2 November 2001 in the District of Columbia, Florida, New Jersey and New York resulted from the intentional delivery of $B$ anthracis spores through mailed letters or packages. The median age of the patients was 56 years (range, 43-73), seven were men, and except for one, all were known or believed to have processed, handled, or received letters containing $B$ anthracis spores. The median incubation period from the time of exposure to onset of symptoms, when known $(\mathrm{n}=6)$, was four days (range, four to six). Symptoms at initial presentation included fever or chills $(n=10)$, sweats $(n=7)$, fatigue or malaise $(n=10)$, minimal or non-productive cough $(n=9)$, dyspnoea $(n=8)$, and nausea $(\mathrm{n}=9)$. The median white blood cell count was $9.8 \times 10^{3} / \mathrm{mm}^{3}$ (range, 7.5-13.3), often with increased neutrophils and band forms. Nine patients had raised serum transaminase concentrations, and six were hypoxic. All 10 patients had abnormal chest $x$ rays; abnormalities included infiltrates $(n=7)$, pleural effusion $(n=8)$, and mediastinal widening $(n=7)$. Computed tomography of the chest was performed on eight patients, and mediastinal lymphadenopathy was present in seven. With multidrug antibiotic regimens and supportive care, the survival of patients $(60 \%)$ was much higher than previously reported.

\section{Meningitis}

Anthrax meningitis can occur as an end stage process of any of the forms of anthrax. The clinical signs of meningitis, together with the appearance of blood in cerebrospinal fluid, are usually followed by loss of consciousness and death. ${ }^{49-51}$ The prognosis of this form of anthrax is extremely poor.

\section{LABORATORY INVESTIGATIONS}

Presumptive diagnosis in a hospital microbiology laboratory is based on direct Gram's stained smear of the skin lesion (vesicle or eschar), blood, or cerebrospinal fluid, demonstrating encapsulated, large Gram positive bacilli (box car shaped) in short chains. After incubation for 18-24 hours, growth occurs on blood agar and shows the characteristic morphology of grey/white, flat colonies, $2-5 \mathrm{~mm}$ in diameter, with irregular edges. Blood cultures are usually positive within six to 24 hours. A buffy coat Gram stain of blood is often positive in advanced disease. Any presumptive colonies of $B$ anthracis must be referred to the appropriate reference laboratory for confirmation. Nasal swab cultures may be used for epidemiological purposes, but have no role in accurately predicting the risk of subsequent clinical disease. Serological testing is only of use retrospectively and requires acute and convalescent sera for comparison. In cases of cutaneous anthrax, antibodies to protective antigen or to the capsule develop in $68-92 \%$ of patients. ${ }^{51}$ In one study of 12 patients with confirmed cutaneous anthrax, 11 had a positive titre $(\geqslant 1 / 128)$ to protective antigen by electrophoretic immunotransblotting and 11 were positive (cut off point, 1/32) for anticapsule antibodies as measured by enzyme linked immunosorbent assay. ${ }^{52}$ Samples were taken six weeks after development of the disease.

\section{ANTIBIOTIC TREATMENT}

Penicillin has long been considered the drug of choice and only rarely has penicillin resistance been found in naturally occurring strains. In vitro $B$ anthracis is susceptible to penicillins, fluoroquinolones, tetracycline, chloramphenicol, aminoglycosides, macrolides, imipenem/meropenem, rifampicin, and vancomycin. The organism is resistant to cephalosporins, trimethoprim, and sulfomanides.

Table 1 shows the current guidelines for the recommended treatment of inhalation anthrax, as issued by the Center for Disease Control. ${ }^{53}$ Because the Ames strain causing the recent infections in the USA has shown the presence of constitutive and inducible $\beta$ lactamases, the treatment of systemic anthrax with penicillin or amoxicillin alone is not now recommended. ${ }^{53}$ For mild cases of cutaneous anthrax, treatment with ciprofloxacillin (500 mg twice daily), doxycycline ( $100 \mathrm{mg}$ twice daily), or amoxicillin (500 mg three times daily) is recommended. ${ }^{3}$ In the context of a bioterrorist attack, treatment should continue for 60 days as opposed to seven to 10 days for naturally acquired disease. 
Table 1 Treatment protocols for inhalation anthrax

\begin{tabular}{|c|c|c|}
\hline Patient category & Intravenous (IV) treatment & Long term treatmentł \\
\hline Adult* & $\begin{array}{l}\text { Ciprofloxacin } 400 \mathrm{mg} \text { IV bd or doxycycline } 100 \mathrm{mg} \text { IV bd } \\
\text { plus } 1 \text { or } 2 \text { other antibiotics } \dagger\end{array}$ & $\begin{array}{l}\text { Switch to oral treatment when clinically appropriate. Ciprofloxacin } 500 \\
\mathrm{mg} \text { bd or doxycycline } 100 \mathrm{mg} \text { bd to complete } 60 \text { days }\end{array}$ \\
\hline Children & $\begin{array}{l}\text { Ciprofloxacin } 10-15 \mathrm{mg} \text { IV bd. Doxycycline }>8 \text { years }>45 \\
\mathrm{~kg}: 100 \mathrm{mg} \text { IV bd } 8 \text { years }<45 \mathrm{~kg} \text { or }<8 \text { years: } 2.2 \mathrm{mg} / \mathrm{kg} \\
\mathrm{bd}+1 \text { or } 2 \text { other antibiotics } \dagger\end{array}$ & $\begin{array}{l}\text { Switch to oral antibiotic when clinically appropriate. Ciprofloxacin } \\
10-15 \mathrm{mg} / \mathrm{kg} \text { bd or doxycycline (same dose regimen) to complete } 60 \\
\text { days }\end{array}$ \\
\hline \multicolumn{3}{|c|}{$\begin{array}{l}\text { Once patients have stabilised clinically, the IV treatment may be switched to oral and monotherapy may be used to complete the } 60 \text { day course. Other } \\
\text { antibiotics that are active in vitro against the current strain are: ampicillin, penicillin, clindamycin, clarithromycin, imipenem/meropenem, vancomycin, } \\
\text { rifampicin, and chloramphenicol. } \\
\text { *Pregnant women and immunocompromised patients should receive the same treatment; } † \text { consider steroids with severe oedema or meningitis; } \ddagger \text { one drug } \\
\text { may be used when the patient has stabilised. } \\
\text { bd, twice daily. }\end{array}$} \\
\hline
\end{tabular}

\begin{abstract}
"Because the Ames strain causing the recent infections in the USA has shown the presence of constitutive and inducible $\beta$ lactamases, the treatment of systemic anthrax with penicillin or amoxicillin alone is not now recommended"
\end{abstract}

Postexposure prophylaxis is not recommended for asymptomatic people, unless public health or police authorities deem they have been exposed to a credible threat of anthrax spores. A long period (60 days) of prophylaxis is recommended because of the prolonged latency period that can elapse before germination of the inhaled spores occurs. ${ }^{31}$ Ciprofloxacin is currently considered prophylaxis of choice and table 2 shows the existing recommendations.

\section{VACCINATION}

Vaccination is the most cost effective form of mass protection. Although the first anthrax animal vaccine was developed by Pasteur in 1881, human vaccines did not emerge until the middle of the 20th century. Although the current vaccines available provide effective protection, they do suffer from several problems, namely: lack of standardisation, the relatively high expense of production, the requirement for repeated dosing, and the associated transient side effects. ${ }^{54}$

\section{Animal vaccines}

Pasteur demonstrated protection against anthrax by immunisation in 1881 using a heat attenuated strain. However, problems with declining potency and variations in virulence led to the search for a more effective and stable vaccine. A Sterne attenuated spore vaccine, based on an avirulent nonencapsulated $34_{\mathrm{F} 2}$ strain, derived from a subculture from a case of bovine anthrax, was developed. This has proved to be extremely safe and effective, requiring little modification. Although extremely effective, repeated vaccinations are required for longterm protection because a single dose will only provide immunity for about a year. ${ }^{556}$

\section{Human vaccines}

The former USSR $^{57}$ and China ${ }^{58}$ use vaccination in humans with live spores, either by scarification of subcutaneous injection. The Russians are known to use a strain STI-1, analogous in its derivation to the Sterne $34_{\mathrm{F} 2}$ strain. Although analagous in many ways, current UK and US vaccines did develop along slightly different routes. The current UK vaccine (licence numbers 1511/0037 and 1511/0058) consists of an alum precipitated, cell free filtrate of an aerobic supernatant from the non-capsulated Sterne strain of Banthracis. ${ }^{59}$ In the production of the UK vaccine, a protein hydrolysate was preferred to synthetic 528 medium as used in US vaccine production. ${ }^{60}$ Downstream processing consists of a filtration step to remove bacterial cells, along with oedema factor and lethal factor. Sterile material, now largely composed of protective antigen, the essential protection immunogen, is alum precipitated at $\mathrm{pH}$ 6.0.

The UK vaccine was introduced for workers in at risk occupations in $1965,{ }^{61}$ and licensed for human use in 1979 after biological agents first fell under the European Directive 75/319/EEC. At present, on empirical grounds, boosters are administered to vaccinees six months after the initial series of three doses (zero, three, and six weeks), and annually thereafter.

The US vaccine, from the start, was based on cultures in synthetic medium, which initially was " 528 medium" ${ }^{.6}$ After subsequent modifications, including modifications of 528 to 599 and then to 1095, the US vaccine used today (product licence number 99) is an alhydrogel absorbed, cell free culture

Table 2 Recommended prophylaxis after exposure to Bacillus anthracis

\begin{tabular}{|c|c|c|}
\hline Antimicrobial agent & Adults & Children \\
\hline $\begin{array}{l}\text { Oral fluoroquinolones } \\
\text { Ciprofloxacin }\end{array}$ & $500 \mathrm{mg} \mathrm{bd}$ & $\begin{array}{l}20-30 \mathrm{mg} / \mathrm{kg} \text { of body mass daily, divided into doses-as a } \\
\text { guide } \\
10 \mathrm{~kg}: 125 \mathrm{mg} \text { bd } \\
20 \mathrm{~kg}: 250 \mathrm{mg} \text { bd } \\
30 \mathrm{~kg}: 375 \mathrm{mg} \text { bd } \\
40 \mathrm{~kg}: \text { as for adult }\end{array}$ \\
\hline $\begin{array}{l}\text { If fluoroquinolones are not available or are contraindicated } \\
\text { Doxycycline }\end{array}$ & $100 \mathrm{mg} \mathrm{bd}$ & $5 \mathrm{mg} / \mathrm{kg}$ body mass/day divided into two doses \\
\hline
\end{tabular}

Ciprofloxacin is not licensed for use in children or pregnant women. There have been no formal studies of the use of ciprofloxacin during pregnancy, but it is unlikely to be associated with a high risk of abnormalities of fetal development. There is some evidence that the use of fluoroquinolones in children (including use by breast feeding mothers) may be associated with tendinopathy and arthropathy. If $B$ anthracis exposure is confirmed, the organism must be tested for penicillin susceptibility. If susceptible, exposed persons may be treated with oral amoxicillin as an alternative to ciprofloxacin or doxycycline $(40 \mathrm{mg} / \mathrm{kg}$ of body mass/day in divided doses 8 hourly; not to exceeed $500 \mathrm{mg}$, three times daily). Pharmacokinetic studies have shown that ciprofloxacin achieves far higher concentrations in lung macrophages than penicillin, and is therefore a more effective prophylactic antibiotic. The risk of adverse effects must be weighed against the risk of developing a serious disease. Ciprofloxacin has the added advantage that it is also an effective prophylactic treatment for other potential agents that may be used in deliberate release scenarios, such as plague and tularaemia. bd, twice daily. 


\section{Take home messages}

- Bacillus anthracis has long been considered a potentia biological warefare agent and the events following September 11 give cause for concern to the West

- It has been calculated that the release of $50 \mathrm{~kg}$ of dried anthrax powder by aerosolisation for two hours on a city of 500000 inhabitants would almost certainly lead to a rapid total breakdown in medical resources and civilian infrastructures

- Anthrax can take three different disease forms: cutaneous, gastointestinal, and inhalation anthrax, with cutaneous anthrax being the most common, but inhalation anthrax probably being the most likely form in the context of a bioterrorist attack

- Anthrax is susceptible to antibiotics, including penicillin and amoxicillin, but vaccination would be the most efficient and cost effective form of mass protection, although all vaccines to date suffer from several problems

- Improved vaccines and treatment modalities need to be developed to combat this ever increasing threat

filtrate of strain V77O-NPI-R (non-encapsulated, nonproteolytic variation of a 1951 bovine isolate from Florida) grown anaerobically in a fermenter.

It was licensed in 1972 for administration to those in at risk occupations, is not licensed for use in children or pregnant women, and at present is not available for civilian use. The vaccine is licensed to be given in a six dose series over an 18 month period. In a study, using a monkey model, inoculation with this vaccine at zero and two weeks was completely protective against an aerosol challenge at eight and 38 weeks and $88 \%$ effective at 100 weeks. ${ }^{62}$

\section{Future vaccines}

Considerable effort has been expended into developing next generation vaccines that would meet current licensing criteria, in addition to having improved performance characteristics. ${ }^{54-56}$ The favourites are subunit vaccines whose active ingredient is whole length $(83000 \mathrm{kDa})$ recombinant protective antigen. Host organisms so far proposed have included a modified Sterne strain, ${ }^{63}$ strain ANR of $B$ anthracis, ${ }^{64}$ Bacillus subtilis, ${ }^{65}$ and Escherichia coli. ${ }^{66}$ Ideally, such new vaccines would be given orally or intranasally and be protective after a single dose. Only time will tell.

\section{THE FUTURE}

In the early days of microbiology, some 125 years ago, anthrax was important as a damaging disease of domesticated animals and the farming economy. This problem was realised and effective countermeasures with vaccines deployed. Once again it is necessary to re-focus on anthrax, but this time as a bioterrorist agent. However, analysis of the whole genome set of $B$ anthracis (Ames strain) is now under way and to date the plasmids pXO1 and pXO2 have been sequenced..$^{67}{ }^{68}$ Updates on the chromosomal sequence can be accessed at TIGR (the Institute for Genomic Research) website (www.tigr.org). With such information as a starting point I have no doubt that researchers will once again rise to the occasion and be able to identify new targets for vaccine and treatment modalities. This has already started to occur with the recent reports concerning identification of the cellular receptor for anthrax toxin ${ }^{69}$ and the crystal structure of the anthrax lethal factor. ${ }^{70}$

\section{CONCLUSIONS}

It is hard to find a precedent for such success by an "outlaw" group against any country in recent times. It is equally hard to find such success against a major Western power since the early colonial period, and such new strategic vulnerability remains to be fully assessed. In the USA and Western democracies there is a concern that the attacks of 11 September 2001 and the subsequent anthrax attacks are the beginning, rather than end, of terrorist attacks.

\section{REFERENCES}

1 Bush LM, Abrams BH, Beall A, et al. Index case of fatal inhalational anthrax due to bioterrorism in the United States. N Engl J Med 2001;345: 1607-10.

2 Spencer RC, Wilcox MH. Agents of biological warfare. Rev Med Microbiol 1993;4:138-43.

3 Inglesby TV, Henderson DA, Bartlett JG, et al. Anthrax as a biological weapon. JAMA 1999;281:1735-45.

4 Spencer RC, Lightfoot NF. Preparedness and response to bioterrorism. J Infect 2001:43:104-10.

5 Redmond C, Pearce M, Manchee RJ, et al. Deadly relic of the Great War. Nature 1998;393:747-8.

6 Wheelis M. Biological sabotage in World War I. In: Geissler E, van Courtland Moon JE, eds. Biological and toxin weapons: research, development and use from the Middle Ages to 1945. Oxford: Oxford University Press, 1999:35-62.

7 Carter GB. Chemical and biological defence at Porton Down: 1916-2000. London: HMSO, 2000.

8 Carter GB. Biological warfare and biological defence in the United Kingdom: 1940-1979. Journal of the Royal United Services Institute for Defence Studies 1992;137:67-74.

9 Guillemin J. Anthrax: the investigation of a deadly outbreak. Berkley, California: University of California Press, 1999.

10 World Health Organisation. Health aspects of chemical and biological weapons. Geneva: WHO, 1970.

11 Lightfoot N, Wale M, Spencer R, et al. Appropriate responses to bioterrorist threats. BM 2001;323:877-8.

12 Ala'Aldeen D. Risk of deliberately induced anthrax outbreak. Lancet 2001;358:1386-8.

13 Quinn CP, Turnbull PCB. Anthrax. In: Collier L, Balows A, Sussman M, eds. Topley and Wilson's principles of bacteriology, virology and immunity, Vol. 3, 9th ed. London: Edward Arnold, 1998:799-818.

14 Dixon TC, Meselson M, Guillemin J, et al. Anthrax. N Engl J Med 1999:341:815-26.

15 Swartz MN. Recognition and management of anthrax-an update. N Engl J Med 2001;345: 1607-10.

16 Baillie L, Read TD. Bacillus anthracis: a bug with attitude. Curr Opin Microbiol 2001;4:78-81.

17 Turnbull PCB. Definitive identification of Bacillus anthracis - a review. J Appl Microbiol 1999;2:237-40.

18 Keim P, Kalif A, Schupp J, et al. Molecular evolution and diversity in Bacillus anthracis as detected by amplified fragment length polymorphism markers. J Bacteriol 1997;3:818-24.

19 Keim P, Price LB, Klevystka AM, et al. Multiple-locus variable number tandem repeat analysis reveals genetic relationships with Bacillus anthracis. J Bacteriol 2000;182:2928-36

20 Jackson PJ, Hugh-Jones ME, Adair DM, et al. PCR analysis of tissue samples from the 1979 Sverdlovsk anthrax victims: the presence of multiple Bacillus anthracis strains in different victims. Proc Natl Acad $\mathrm{Sci}$ U S A 1998:95:1224-9.

21 Manchee RJ, Brosler MG, Stagg AJ, et al. Formaldehyde solution effectively inactivates spores of Bacillus anthracis on the Scottish Island of Gruinard. App/ Environ Microbiol 1994;60:4167-71.

22 Carman JA, Hamblelon P, Melling J. Bacillus anthracis, in isolation and identification of micro-organisms of medical and veterinary importance. In Collins CH, Grange GM, eds. Society of Applied Bacteriology Technical Series 21. London: Academic Press, 1985:207-14.

23 Knisely RF. Selective medium for Bacillus anthracis. J Bacteriol 1966:92:784-6.

24 Hanna P. Anthrax pathogenesis and host response. Curr Top Microbiol Immunol 1998;225: 13-35.

25 Little SF, Ivins BE. Molecular pathogenesis of Bacillus anthracis infection. Microbes Infect 1999:1:131-9.

26 Leppla SH. The anthrax toxin complex. In: Alouf J, Freer JH, eds. Sourcebook of bacterial protein toxins. London: Academic Press 1991:277-302

27 Leppla SH. Anthrax toxin edema factor; a bacterial adenylate cyclase that increases cyclic AMP concentrations of eukaryotic cells. Proc Natl Acad Sci U S A 1982:79:3162-6.

28 Leppla SH. Bacillus anthracis calmodulin-dependent adenylate cyclase: chemical and enzymatic properties and interactions with eukaryotic cells. Adv Cyclic Nucleotide Protein Phosphonylation Res 1984;17:189-98.

29 O'Brien J. Friedlander A, Drier T, et al. Effects of anthrax toxin compounds on human neutrophils. Infect Immun 1985;47:306-10.

30 Makins S-I, Ucluda I, Terakads N, et al. Molecular characterisation and protein analysis of the cap region, which is essential for encapsulation in Bacillus anthracis. J Bacteriol 1989;171:722-30.

31 Friedlander AM, Welkoss L, Pitt MLM et al. Postexposure prophylaxis against experimental inhalation anthrax. J Infect Dis 1993;167:1239_ 43

32 Lincoln RE, Walker JS, Klein F, et al. Value of field data for extrapolation in anthrax. Fed Proc 1967:26:1558-62.

33 Dahlgren CM, Buchanan LM, Decker HM, et al. Bacillus anthracis aerosols in goat hair processing mills. Am J Hyg 1960;72:24-31. 
34 Myenye KS, Siziya S, Peterson D, Factors associated with human anthrax outbreak in the Chikupo and Nganda villages of Murewa district in Mashonaland East Province, Zimbabwe. Cent Afr J Med 1996;42:312-15.

35 Abdenour D, Larouze B, Dalichaouche $M$, et al. Familial occurrence of anthrax in Eastern Algeria. J Infect Dis 1987;155:1083-4.

36 Turner M. Anthrax in humans in Zimbabwe. Cent Afr J Med 1980;26:160-1.

37 Nalin DR, Sultana B, Sahunja R, et al. Survival of a patient with intestinal anthrax. Am J Med 1977;62:130-2.

38 Whitford HW. A guide to the diagnosis, treatment and prevention of anthrax. World Health Geneva: Organisation 1987.WHO/ZOON/ 87.163.

39 Christie AB. Anthrax. In: Infectious diseases, epidemiology and clinical practice, 4th ed. Edinburgh: Churchill Livingstone, 1987:983-1003.

40 Kobuch WE, Davis J, Fleischer K, et al. A clinical and epidemiological study of 621 patients with anthrax in Western Zimbabwe. Salisbury Med Bull 1990;68(suppl):34-8

41 Ndyabahinduka DGK, Chu IH, Abdou AH, et al. An outbreak of human gastro-intestinal anthrax. Ann 1st Super Sanita 1984;20:205-8.

42 Jernigan JA, Stephens DS, Ashford DA, et al. Bioterrorism-related inhalational anthrax: the first 10 cases reported in the United States. Emerg Infect Dis 2001;7:933-44.

43 Brachman P. Inhalation anthrax. Ann N Y Acad Sci 1980;353:83-93.

44 Shafazand S, Doyle R, Ruoss S, et al. Inhalational anthrax: epidemiology, diagnosis and management. Chest 1999;116:1369-76.

45 Meselson M, Guillemin J, Hugh-Jones M, et al. The Sverdlovsk anthrax outbreak of 1979. Science 1994;266:1202-8.

46 Albrink WS, Brook SM, Biron R, et al. Human inhalation anthrax: a report of three fatal cases. Am J Pathol 1960:36:457-71.

47 Plotkin SA, Brachman PS, Utall M, et al. An epidemic of inhalation anthrax, the first in the twentieth century. Am J Med 1960;29:9921001

48 Enticknap JB, Galbraith NS, Tomlinson AN, et al. Pulmonary anthrax caused by contaminated sacks. Br J Ind Med 1968;25:72-4.

49 Haight TH. Anthrax meningitis: review of literature and report of two cases with autopsies. Am J Med Sci 952;224:57-69.

50 Tahernia AC, Hashemi GH. Survival in anthrax meningitis. Pediatrics 1972:50:329-33.

51 Friedlander AM. Anthrax: clinical features, pathogenesis and potential biological warfare threat. In: Remington JS, Swartz MN, eds. Current clinical topics in infectious diseases, Vol. 20. Malden, Massachusetts: Blackwell Sciences, 2000:335-49.

52 Harrison LH, Ezzell JW, Abshire TG, et al. Evaluation of serologic tests for diagnosis of anthrax after an outbreak of cutaneous anthrax in Paraguay. J Infect Dis 1989;160:706-10.
53 Update. Investigation of bioterrorism-related anthrax and interim guidelines for exposure management and antimicrobial therapy. MMWR Morb Mortal Wkly Rep 2001;50:909-19.

54 Baillie, L. The development of new vaccines against Bacillus anthracis. J Appl Microbiol 2001;91:609-13.

55 Turnbull PCB. Anthrax vaccines: past, present and future. Vaccine 1991;9:533-9.

56 Turnbull PCB. Current status of immunisation against anthrax: old vaccines may be here to stay for a while. Curr Opin Infect Dis 2000;13:113-20

57 Shylakov EN, Rubenstein E. Human live anthrax vaccine in the former USSR. Vaccine 1994;12:727-30.

58 Dong SL. Progress in the control and research of anthrax in China. Salisbury Med Bull 1990;68(suppl): 104-5.

59 Hambleton P, Carman JA, Melling J. Anthrax: the disease in relation to vaccines. Vaccine 1984;2:125-32.

60 Wright GG, Hedberg MA, Stein JB. Studies on immunity in anthrax III. Elaboration of protective antigen in a chemically defined non-protein medium. J Immunol 1954;72:263-9.

61 Anonymous: Vaccine against anthrax. BM 1965;ii:717-18.

62 Ivins BE, Fellows P, Pitt MLM, et al. Efficacy of standard human anthrax vaccine against Bacillus anthracis aerosol spore challenge in rhesus monkeys. Salisbury Med Bull 1996;87:125-6.

63 Ivins BE, Pitt MLM, Fellows PF, et al. Comparative efficacy of experimental anthrax vaccine candidates against inhalation anthrax in rhesus macaques. Vaccine 1998;16:1141-8.

64 Bernard JP, Friedlander AM. Vaccination against anthrax with attenuated recombinant strains of Bacillus anthracis that produce protective antigen. Infect Immun 1999;67:562-7.

65 Baillie L, Moir A, Manchee R. The expression of the protective antigen of Bacillus anthracis and Bacillus subtilis. J App/ Microbiol 1998:84:741-6.

66 Gupta P, Waheed SM, Bhatnagar R. Expression and purification of the recombinant protective antigen of Bacillus anthracis. Protein Expr Purif 1999; 16:369-76.

67 Okinaka RT, Cloud K, Hampton O, et al. Sequence and organisation of $\mathrm{pXO1,} \mathrm{the} \mathrm{large} \mathrm{Bacillus} \mathrm{anthracis} \mathrm{plasmid} \mathrm{harbouring} \mathrm{the} \mathrm{anthrax} \mathrm{toxin}$ genes. J Bacteriol 2000;181:6509-15.

68 Okinaka RT, Cloud K, Hampton O, et al. Bacillus anthracis plasmid pXO2, complete sequence 2000. Genbank Accession NC 002146 (http://www, ncbi.nlm.nih.gov/Entrex/index.html).

69 Bradley KA, Mogridge J, Mourez M, et al. Identification of the cellular receptor for anthrax toxin. Nature 2001;414:225-9.

70 Paunifer AD, Wong TY, Schwarzenbacher R, et al. Crystal structure of the anthrax lethal factor. Nature 2001;414:229-33. 